九州大学学術情報リポジトリ

Kyushu University Institutional Repository

Effects on Growth and Seed Yield of Small Seed Soybean Cultivars of Flooding Conditions in Paddy Field

Cho, Jin-Woong

Collage of Agricultural and Life Science, Chungnam National University

Yamakawa, Takeo

Faculty of Agriculture, Kyushu University

https://doi.org/10.5109/9228

出版情報：九州大学大学院農学研究院紀要. 51 (2)，pp. 189-193，2006-10-27. Faculty of Agriculture, Kyushu University

バージョン：

権利関係 : 


\title{
Effects on Growth and Seed Yield of Small Seed Soybean Cultivars of Flooding Conditions in Paddy Field
}

\author{
Jin-Woong CHO $^{1}$ and Takeo YAMAKAWA* \\ Laboratory of Plant Nutrition, Division of Soil Science and Plnt Production, Department of Plant Resources, \\ Faculty of Agriculture, Kyushu University, 6-10-1 Hakozaki, Fukuoka 812-8581, Japan \\ (Received May 22, 2006 and accepted July 24, 2006)
}

\begin{abstract}
Field studies were on a commerce silt loam soil in a paddy field using three soybean (Glycine max L.) cultivars Pungsan-namulkong, Sobaeg-namulkong and Saebyeolkong of determinate growth type, which have different productivity. The flood duration was done for 3, 5, 7 and 9 days, respectively when plants were at the vegetative (V5 to V6) stages filled with tap water to $2 \mathrm{~cm}$ above the level of the soil surface by irrigation. After removal of flooding, photosynthetic rate reduced in all flooding treatments except for 3 days' flooding. Reduction of photosynthetic rate was relatively lower in Saebyeolkong than any others.

The number of pod and seed decreased as much as the flood period was prolonged. There was a significantly positive relationship $\left(R^{2}=0.50, p<0.01\right)$ between the ratio of seed yield on branch stem against that on main stem and the seed yield of three soybean cultivars treated with flooding. Also, the relationship between the seed yield and the relative yield of the flooded soybean to non-flooded one had a high positive significance, and there was more significant difference in relative yield of branch stem $\left(R^{2}=0.91, p<0.01\right)$ than that of main stem $\left(\mathrm{R}^{2}=0.88, \mathrm{p}<0.01\right)$. From these results, it was ascertained that the high yield soybean cultivar (Saebyeolkong) under the upland field condition (Cho et al., 2005) has the highest ability of productivity under the paddy field condition in the rainy season.

From above results, the accumulation of biomass was considerably reduced by longer exposure of soybeans against flooding. Flooding stress was also decreased in the photosynthesis and the seed yield of soybeans. The seed yield was remarkably reduced from flood duration of 3 days. That is, a critical day for drainage after flooding might be 3 days.
\end{abstract}

\section{INTRODUCTION}

The flooding effect on the plant growth is usually attributed to an insufficient oxygen supply to maintain root respiration. Excessive water stress may be detrimental to root growth, nodule formation, carbon assimilation and $\mathrm{N}_{2}$ fixation in soybean (Sallan and Scott, 1987) and it may be sensitive response at V5 to R5 stage in different growth stages of soybean. Also, the flood effect on the growth of soybean were manifested in the yellowing and abscission of leaves at the lower nodes, stunting, and reduced dry weight and seed yield (Scott et al., 1989). Soybean flooded at vegetative stage reduced leaf area, dry weight and plant height (Choi et. al., 1996; Choi et al., 1995; Griffin and Saxton, 1988; Linkemer et al., 1998; Scott et al., 1989). Specially, Griffin and Saxton (1988) stated that soybean flooded at V6 stage had severe chlorosis and stunting after exposed to excessive water for 4 days and also, these researchers reported that crop growth rate has been usually affected only when the flooding stress was applied for more than 2 days.

On the other hand, in Korea, in order to elevate soybean yield, it has been to encourage soybean cultivation in rice paddy field (Park et al., 2001). However, when soybean was cultivated on the rice paddy field, however, the excessive water in soil was harmful to soybean growth and yield (Seong et al., 2000). In the southern Korea, soybean has been cultivated with late

\footnotetext{
1 Division of Plant Science and Resources, Collage of Agricultural and Life Science, Chungnam National University, 305-764, Korea

* Corresponding author (E-mail: yamakawa@agr.kyushu-u.ac.jp)
}

planting (after mid-June) which is a common limiting factor for soybean. However, because the rainy season is usually common during the summer season from June to August, when soybean is grown on a paddy field, the damage with excessive water is more serious compared to the cultivation on an upland field. The response against excessive water of soybean from emergence to prior flowering stage (vegetative stage) must be very important for the soybean cultivation in this season. Therefore, this study was conducted to investigate the effects on yield and growth and to determine a critical drainage day after flooding at V5 toV6 stage of soybean.

\section{MATERIALS AND METHODS}

Field studies were at the National Honam Agricultural Experiment Station on Junbuk Province in the southeastern Korea $\left(35^{\circ} 58^{\prime} \mathrm{N}, 127^{\circ} 13^{\prime} \mathrm{E}\right)$ on a commerce silt loam soil on a paddy field using three soybean cultivars (Pungsan-namulkong, Sobaeg-namulkong and Saebyeolkong) of determinate growth type. These cultivars have high productivity under the upland field condition (Cho et al., 2005), and Saebyeolkong has especially high ability among them.

Seeds were sowed with two and with the planting density of $70 \times 10 \mathrm{~cm}$ on June 16, 2003. Based on soil test recommendations, fertilizer was applied prior to planting at a rate of $3.0-3.0-3.4 \mathrm{~g}(\mathrm{~N}-\mathrm{P}-\mathrm{K})$ per $\mathrm{m}^{2}$ as basal dressing. Weeds, diseases, and insects were controlled by recommended pesticides.

Experimental design was a split plot arrangement with three replications. The flooding was done for 3,5 , 7 and 9 days, respectively when plants were at the vegetative (V5 to V6, Fehr and Caviness, 1977) stages 
by filling with tap water to $2 \mathrm{~cm}$ above the level of the soil surface by irrigation. Control plants remained well watered during the experiment. The plant samples for measuring the parameter for relative growth were obtained after different flood durations, respectively.

The photosynthetic rate was measured using portable photosynthesis measuring device (LCA-4, UK). The measurements were carried out the $5^{\text {th }}$ leaves of main stem on $1,3,5,7$ and 9 days after the removal of flooding for 3, 5, 7 and 9 days. Those were taken from 9: 30 in the morning to $2: 30$ in the afternoon with six replications per each cultivar. The light intensity used to measure the photosynthetic rate was in the range of 1700 to $2000 \mu \mathrm{mol} \mathrm{m}{ }^{-2} \mathrm{~s}^{-1}$ photosynthetically active radiation (PAR). The $\mathrm{CO}_{2}$ concentration was 330 to $370 \mu \mathrm{L}$ $\mathrm{L}^{-1}$ and the flow rate of the air was $400 \mathrm{~mL} \mathrm{~min}{ }^{-1}$.

Yield and yield components were determined from 10 plants per each flood duration which were randomly selected and analyzed for nod number, pod number, seed yield and seed weight.

\section{RESULTS AND DISCUSSION}

Table 1 showed the relative growth of plant treated by flooding compared to non-flooding on three soybean cultivars to assess the effects of the removal of flooding after various flood duration at V5 to V6 stage. All of three cultivars decreased main stem length, leaf area, number of leaf and dry matter by all flood duration, especially more than 5 days' flooding. Bacanamwo and Purcell (1999) reported the flooding inhibited biomass accumulation and $\mathrm{N}_{2}$ fixation of soybean, and there was no effect on biomass for 7 days' flooding but was a significant damage for 14 days because the total $\mathrm{N}$ content of plants was significantly decreased and the yellowing of soybean leaves was evident by flooding longer than 7 days.

Generally, shoots are more starved than roots under nutrient deficits. This could decrease photosynthesis and overall dry matter accumulation (Wilson, 1988). In this experiment, the photosynthetic rate may be used to accounting for recovery level to days after the removal of flooding in soybeans which were subjected to different duration of flooding. Photosynthetic rate declined in the flooded soybean and it decreased greatly by the longer flooding treatments (Fig. 1). After the removal of flooding, the photosynthetic rate showed gradually declining tendency in all flooding treatments except for 3 days' flooding. Ahamed et al. (2002) stated that the photosynthetic rate of mungbean declined rapidly by progressive water-logging at vegetative stage, and the water-logging might be caused a fast decline in the photosynthetic rate by a mechanism independent to stomatal closure. Also, when the water-logging was removed, the photosynthetic rate increased to a control level in 8 days at vegetative stage. In this experiment, however, the photosynthetic rate of soybean after the removal of flooding decreased continuously independent of any flood periods. Inhibition level of photosynthetic rate was relatively less in Saebyeolkong than any others. Photosynthetic rate in soybean which subjected flooding for 3 days was similar regardless of soybean cultivars, but in the case of longer flooding treatments than 5 days, there was significantly different among soybean cultivars.

As longer flood periods, it was decreased main stem length, number of node, and stem width of soybean at maturity, indicating that prolonged flooding was detrimental factor to their growth (Table 2). Also it was seen that progressive flooding against soybeans tended to be stunted in comparison with non-flooding. This stunting by flooding resulted in main stem lengths that were approximately $16.4 \mathrm{~cm}$ in Saebyeolkong, $5.8 \mathrm{~cm}$ in Pungsan-namulkong and $4.3 \mathrm{~cm}$ in Sobaeg-namulkong shorter than those of non-flooded soybeans cultivars, respectively.

Seed yields of soybean flooded at V5 to V6 stage were significantly affected by the flood duration and

Table 1. Relative growth of plant treated with different flood duration to control plant of three soybean cultivars

\begin{tabular}{|c|c|c|c|c|c|c|}
\hline \multirow{2}{*}{ Cultivars } & \multirow{2}{*}{$\begin{array}{c}\text { Flood } \\
\text { duration } \\
\text { (day) }\end{array}$} & \multirow{2}{*}{$\begin{array}{c}\text { Main stem } \\
\text { length }\end{array}$} & \multirow{2}{*}{$\begin{array}{l}\text { Leaf } \\
\text { area }\end{array}$} & \multirow{2}{*}{$\begin{array}{l}\text { No. of } \\
\text { leaf }\end{array}$} & \multicolumn{2}{|c|}{ Dry matter } \\
\hline & & & & & Leaf & Stem \\
\hline \multirow{4}{*}{ Saebyeolkong } & 3 & 102 & 108 & 103 & 106 & 110 \\
\hline & 5 & 98 & 88 & 96 & 92 & 98 \\
\hline & 7 & 98 & 84 & 87 & 91 & 94 \\
\hline & 9 & 91 & 71 & 65 & 75 & 76 \\
\hline \multirow{4}{*}{$\begin{array}{l}\text { Pungsan- } \\
\text { namulkong }\end{array}$} & 3 & 105 & 111 & 95 & 85 & 97 \\
\hline & 5 & 100 & 104 & 96 & 82 & 97 \\
\hline & 7 & 98 & 94 & 92 & 84 & 84 \\
\hline & 9 & 95 & 92 & 87 & 69 & 79 \\
\hline \multirow{4}{*}{$\begin{array}{c}\text { Sobaeg- } \\
\text { namulkong }\end{array}$} & 3 & 103 & 98 & 98 & 91 & 101 \\
\hline & 5 & 101 & 97 & 95 & 88 & 99 \\
\hline & 7 & 93 & 67 & 82 & 87 & 88 \\
\hline & 9 & 91 & 57 & 61 & 52 & 63 \\
\hline
\end{tabular}

All data were shown in the ratio of value of plant treated with flooding /that of control plant $\times 100(\%)$ 


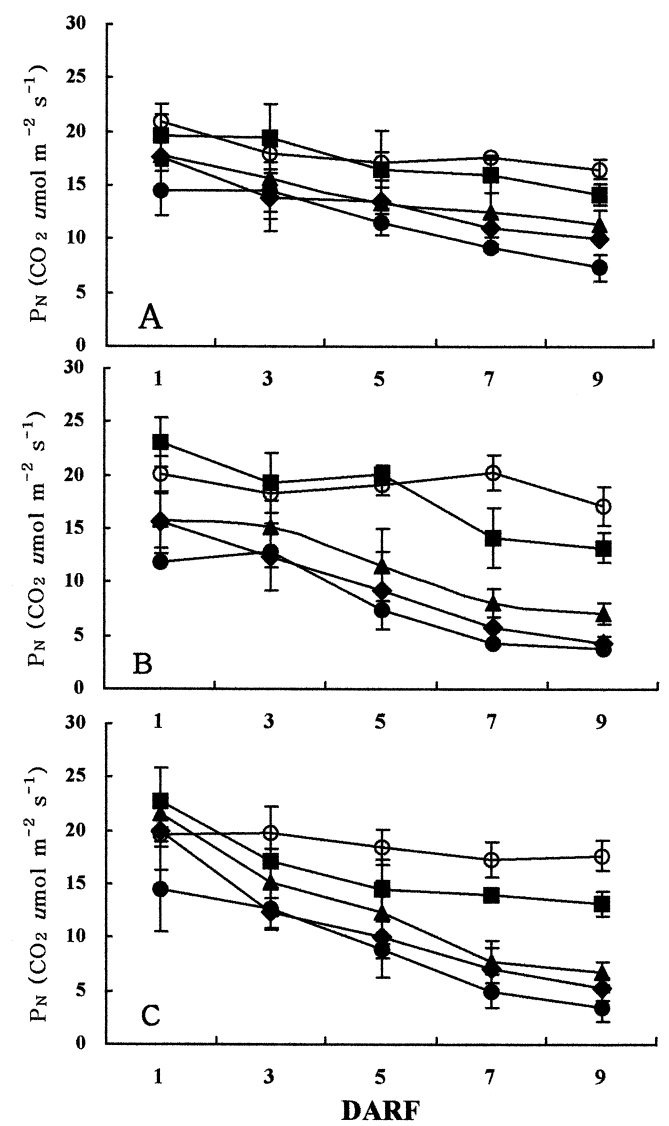

Fig. 1. Photosynthetic rate $\left(\mathrm{CO}_{2} \mu \mathrm{mol} \mathrm{m}^{-2} \mathrm{~s}^{-1}\right)$ of three soybean cultivars after the removal of different flood duration at V5 toV6 stages. DARF; Days after the removal of flooding, $\bigcirc$; non-flooding, $\mathbf{\square}$; 3 days' flooding, $\mathbf{\Delta}$; 5 days' flooding, $\square$; 7 days' flooding, $\mathbf{O}$; days' flood. A; Saebyeolkong, B; Pungsan-namulkong, C; Sobaeg-namulkong. Each symbol with bar is shown mean $\pm \mathrm{SE}$. cultivar. As the flood duration increased, the seed yield generally decreased (Table 2). Reduction of the seed yield in three soybean cultivars showed generally from 3 days flood duration except for Saebyeolkong. At the flooded soybean for 5 days, the seed yield reduced by 9\% in Saebyeolkong, 33\% in Pungsan-namulkong and $44 \%$ in Sobaeg-namulkong, and at the flooding for 9 days, yield reduced by $38 \%, 44 \%$ and $66 \%$ for cultivars in the order, respectively, compared to the seed yield of non-flooded soybean.

The number of pod per $\mathrm{m}^{2}$ was decreased by flooding and it tended to reduce as flood duration increased (Table 2). The number of pod was 39.2 (Saebyeolkong), 46.4 (Pungsan-namulkong), and 57.4 (Sobaeg-namulkong) in non-flooded soybean but when flood duration increased, it decreased sharply by 19.2 , 27.3 and 21.2 in this order, respectively. Also, number of seed per $\mathrm{m}^{2}$ was similar to that of the flooded soybean.

Many reports indicated that soybean was more sensitive against the excessive water in soil on the early reproductive than on the vegetative stages (Griffin and Saxton, 1988; Scott et al., 1989; Choi et al., 1996; Heatherly and Pringle, 1991; Kwon and Lee, 1988). Linkemer et al. (1998) stated that greatest sensitivity to the water-logging occurred during 7 days in the period starting at R3 stage, and the water-logging reduced the seed yield by $93 \%, 67 \%$ and $30 \%$ at the R3, R1 or R5, and V2 stage, respectively. Also, the loss of seed yield under water-logging primarily induced by the decreased pod production which resulted from fewer pods per reproductive nodes in late planting soybean. Board et al. (1999) reported that there was a high significant

Table 2. Yield and yield component of three soybean cultivars treated with different flood duration at V5 to V6 stages

\begin{tabular}{|c|c|c|c|c|c|c|c|c|}
\hline Cultivars & $\begin{array}{c}\text { Flood } \\
\text { duration } \\
\text { (day) }\end{array}$ & $\begin{array}{c}\text { Stem } \\
\text { length } \\
(\mathrm{cm})\end{array}$ & $\begin{array}{l}\text { No. of } \\
\text { node }\end{array}$ & $\begin{array}{l}\text { Stem } \\
\text { width } \\
(\mathrm{mm})\end{array}$ & $\begin{array}{c}\text { No. of } \\
\text { pod } \\
\left(\text { no. } \mathrm{m}^{-2}\right)\end{array}$ & $\begin{array}{c}\text { No. of } \\
\text { Seed } \\
\left(\text { no. } \mathrm{m}^{-2}\right)\end{array}$ & $\begin{array}{c}\text { Seed } \\
\text { yield } \\
\left(\mathrm{g} \mathrm{m}^{-2}\right)\end{array}$ & $\begin{array}{c}100 \text { seed } \\
\text { weight } \\
\text { (g) }\end{array}$ \\
\hline \multirow{5}{*}{ Saebyeolkong } & Con. & 57.3 & 11.6 & 4.43 & 39.2 & 73.7 & 216 & 14.5 \\
\hline & 3 & 55.4 & 10.6 & 4.45 & 37.8 & 76.8 & 220 & 15.0 \\
\hline & 5 & 50.9 & 10.5 & 4.31 & 34.4 & 66.5 & 195 & 14.6 \\
\hline & 7 & 46.3 & 10.8 & 3.76 & 25.4 & 54.1 & 148 & 14.0 \\
\hline & 9 & 44.1 & 10.8 & 3.65 & 19.2 & 43.7 & 134 & 16.0 \\
\hline \multirow{5}{*}{$\begin{array}{l}\text { Pungsan- } \\
\text { namulkong }\end{array}$} & Con. & 46.3 & 13.9 & 4.16 & 46.4 & 96.1 & 221 & 11.4 \\
\hline & 3 & 45.2 & 13.2 & 3.84 & 38.1 & 73.0 & 162 & 11.4 \\
\hline & 5 & 44.1 & 13.1 & 3.64 & 36.4 & 64.9 & 150 & 11.2 \\
\hline & 7 & 39.3 & 13.2 & 2.98 & 30.8 & 59.5 & 122 & 11.3 \\
\hline & 9 & 40.5 & 12.9 & 2.77 & 27.3 & 50.5 & 123 & 12.1 \\
\hline \multirow{5}{*}{$\begin{array}{c}\text { Sobaeg- } \\
\text { namulkong }\end{array}$} & Con. & 34.1 & 11.7 & 4.46 & 57.4 & 104.2 & 237 & 10.1 \\
\hline & 3 & 33.1 & 11.2 & 4.43 & 43.4 & 83.4 & 172 & 10.3 \\
\hline & 5 & 32.1 & 11.4 & 4.01 & 35.6 & 66.0 & 132 & 10.1 \\
\hline & 7 & 30.7 & 10.6 & 3.13 & 29.6 & 54.2 & 94 & 9.8 \\
\hline & 9 & 29.8 & 10.8 & 4.01 & 21.2 & 39.9 & 89 & 10.0 \\
\hline \multicolumn{2}{|c|}{ Cultivars (A) } & $* *$ & ns & ns & * & * & ns & $*$ \\
\hline \multicolumn{2}{|c|}{ Flood duration (B) } & $* *$ & ns & $*$ & $* *$ & $* *$ & $* *$ & ns \\
\hline \multicolumn{2}{|c|}{$\mathrm{A} \times \mathrm{B}$} & $*$ & ns & ns & $*$ & $*$ & $*$ & ns \\
\hline \multicolumn{2}{|c|}{$\mathrm{CV}, \%$} & 16.8 & 15.9 & 22.4 & 20.1 & 18.2 & 17.4 & 10.9 \\
\hline
\end{tabular}

*,** are statistically significant at the 0.05 and 0.01 probability levels, respectively. ns $=$ not significant. 
correlation between the seed yield, the pod number and the seed size in late-planted soybean. Seong et al. (2000) reported the excessive water stress against soybean was more strongly affected by irrigation beginning at pre-flowering than post-flowering stage, because the flooded soybean at post-flowering stage did not reduce growth of vegetative organs significantly.

In this experiment, there was a significantly positive relationship between the ratio the seed yield of branch to that of main stem and the seed yield of three cultivars (Fig. 2A). Also, relationship between the seed yield and the relative seed yield of the flooded soybean to the non-flooded soybean had a highly positive significance. There was more significant difference in the relative yield of branch stem $\left(R^{2}=0.91, p<0.01\right)$ than that of main stem $\left(R^{2}=0.88, p<0.01\right)$. That is, the seed yield of the flooded soybean reduced greater in branch stem part than in main stem (Fig. 2B). Scott and Sallam (1987) showed that the leaves and the branches of soybean were the first plant parts to respond to the prolonged flooding. Flooding treatments affected the $\mathrm{N}$ uptake in soybean, and leaves of flooded soybean had a greater decrease than branch and main stem in $\mathrm{N}$ uptake (Puiatti. and Sodek, 1999). Therefore, the growth response of soybean against flooding may be the most sensitive at leaf and the branch growth and the main
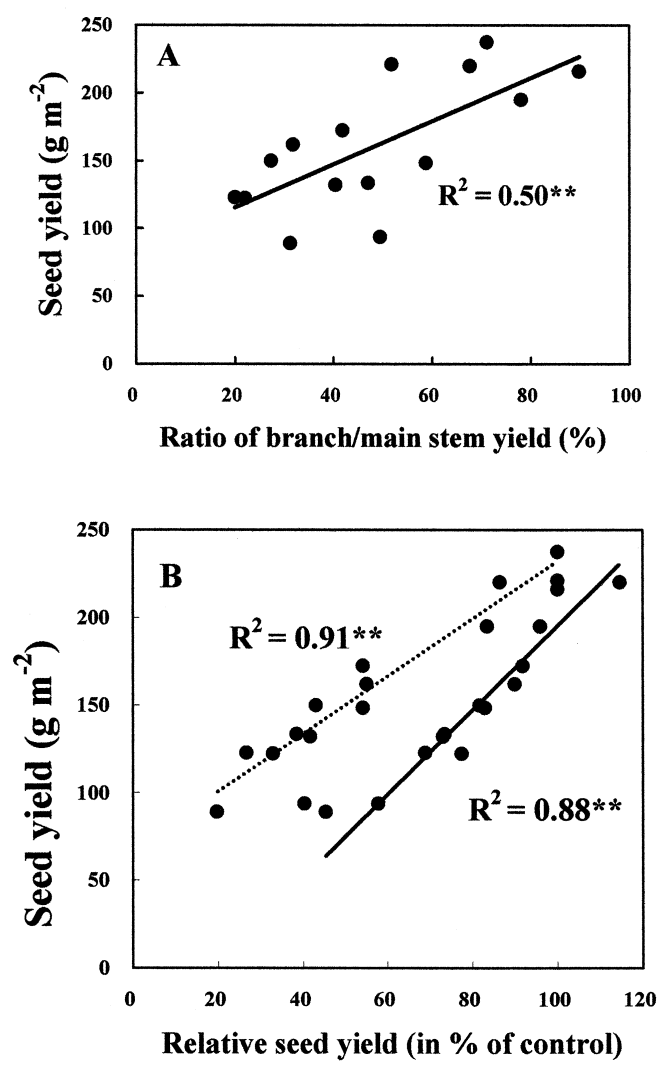

Fig. 2. The relationship between the seed yield and (A) the ratio the seed yield of branch stem to that of main stem or (B) the relative seed yield of three soybean cultivars treated with various flood duration at V5 to V6 stage. Dotted or solid lines in Fig. 2B show the relationship between the seed yield and the relative seed yield of branch stem or that of main stem, respectively. ** shows a significant difference at $\mathrm{p}<0.01$ stem growth may be followed in this order.

Meanwhile, there was a highly significant relationship $\left(\mathrm{R}^{2}=0.83, \mathrm{p}<0.01\right)$ between yield and photosynthetic rate at 9 days after removal flooding in 3, 5, 7, and 9 days flooded three soybean cultivars (Fig. 3). Therefore, longer exposure of plants led to noticeable decrease in photosynthesis and chlorophyll (Yordanova and Popova, 1999) The reduction of photosynthesis with longer exposure of plants to flooding may be caused by the reduction of chlorophyll, transpiration, and activity of RuBP carboxylase. These cumulative effects against flooding had been induced to decline crop growth rate, net assimilation rate, and leaf expansion of plants.

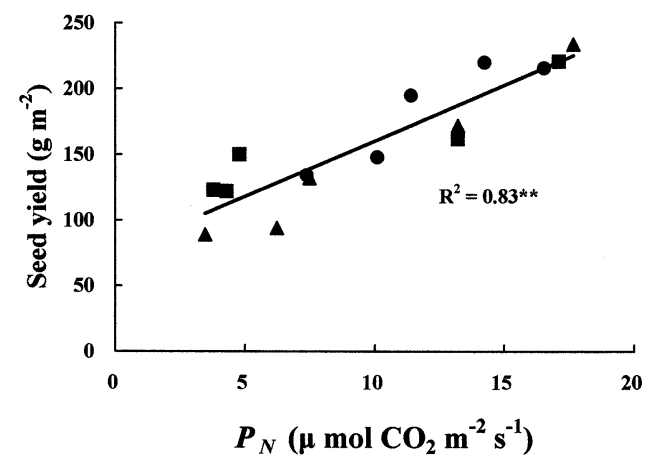

Fig. 3. Relationship between the photosynthetic rate at 9 days after the removal of flooding and the seed yield in three soybean cultivars treated with various flood duration. $* *$ shows a significant difference at $\mathrm{p}<0.01 \mathbf{\square}$; Sebyeolkong, ; Pungsan-namulkong, $\mathbf{\Delta}$; Sobaegnamulkong.

In summary, the accumulation of biomass was considerably reduced by longer exposure of soybeans against flooding. Flooding stress was also decreased in the photosynthesis and the seed yield of soybeans. The seed yield was remarkably reduced from flood duration of 3 days. That is, a critical day for drainage after flooding might be 3 days. Also among three soybean cultivars, Saebyeolkong indicated the most tolerant cultivar with seed yield against flooding stress at vegetative stage in paddy field.

\section{REFERENCES}

Ahmed, S., E. Nawata, M. Hosokawa, Y. Domae and T. Sakuratani 2002 Alterations in photosynthesis and some antioxidant enzymatic activities of mungbean subjected to waterlogging. Plant Sci., 163: 117-123

Bacanamwo, M. and L. C. Purcell 1999 Soybean dry matter and $\mathrm{N}$ accumulation responses to flooding stress, $\mathrm{N}$ sources and hypoxia. J. Exp. Botany, 50: 689-696

Board, J. E., M. S. Kang and B. G. Harvile 1999 Path analysis of the yield formation process for late-planted soybean. Agron. J., 91: 128-135

Cho, J.-W., G.-S. Park, T. Yamakawa and S. Ohga 2005 Comparison of yield in Korean small seed soybean cultivars with main stem and branch production. J. Fac. Agr. Kyushu Univ., 50: 511-519

Choi, K. J., H. S. Lee and Y. W. Kwon 1995 Physiological response of soybean under excessive soil water stress during vegetative growth period. Korean J. Crop Sci., 40: 595-599 
Fehr, W. R. and C. E. Caviness 1977 Stages of soybean development. Iowa Agric. Exp. Stn. Spec. Rep., 80

Griffin J. L. and A. M. Saxton 1988 Response of solid-seeded soybean to flood irrigation. II. Flood duration. Agron. J., 80: 885-888

Heatherly, L. G. and H. C. Pringle 1991 Soybean cultivars response to flood irrigation of clay soil. Agron. J., 83: 231-236

Kwon, Y. W. and M. K. Lee 1988 Physiological responses of soybean plants to flooding at the vegetative growth and the flowering stages. Res. Rept. RDA, 31: 289-300

Linkemer, G., J. E. Board and M. E. Musgrave 1998 Waterlogging effects on growth and yield components in late-planted soybean. Crop Sci., 38: 1579-1584

Park, H. K., Y. J. Oh, H. S. Kim, K. H. Kim, K. S. See and D. Y. Suh 2001 Future prospects for increase production of soybean. International symposium for development strategy for self-production of soybean (Glycine max L.). NHAES. RDA. pp 79-121

Puiatti, M. and L. Sodek 1999 Waterlogging affects nitrogen transport in the xylem of soybean. Plant Physiol. Biochem., 37: $767-773$

Sallam, A. and H. D. Scott 1987 Effects of prolonged flooding on soybeans during early vegetative growth. Soil Sci., 144: $61-66$

Seong, R. C., J. Y. Sohn and S. I. Shim 2000 Responses of soybean cultivars to excessive soil moisture imposed at different growth stages. Korean J. Crop Sci., 45: 282-287

Scott, H. D., J. DeAngulo, M. B. Daniels and L. S. Wood 1989 Flood duration effects on soybean growth and yield. Agron. J., 81: 631-636

Yordanova, R. Y. and L. P. Popova 2001 Photosynthetic response of barley plants to soil flooding. Photosynthtica, 39: 515-520

Wilson, J. B. 1988 A review of evidence on the control of shoot: root ratio, in relation to models. Ann. Botany, 61: 433-449 